\title{
Microbial contamination of disinfectants and antiseptics in four major hospitals in Trinidad
}

\author{
Tswana Gajadhar, ${ }^{1}$ Alicia Lara, ${ }^{1}$ Patricia Sealy, ${ }^{1}$ \\ and Abiodun A. Adesiyun ${ }^{2}$
}

ABSTRACT Objective. To assess the microbial contamination of disinfectants and antiseptics in major hospitals on the Caribbean island of Trinidad.

Methods. For this cross-sectional study, disinfectants and antiseptics were sampled from the pharmacy departments, the pediatric/neonatal wards, and the surgical wards of four hospitals. The samples were cultured for aerobic bacteria on nutrient agar using the surface plating method. The antibiotic sensitivity of bacterial isolates was determined by the disk diffusion method, using 14 antimicrobial agents. We studied a total of 180 disinfectant/antiseptic samples: 60 of chlorhexidine gluconate (Hibitane), 60 of chlorhexidine gluconate and cetrimonium bromide (Savlon), and 60 of methylated spirit.

Results. Of the 180 samples studied, 11 of them (6.1\%) were contaminated by aerobic bacteria. All bacteria isolated were Pseudomonas spp. Of the 11 contaminated samples, 6 of them $(54.5 \%)$ occurred at the pharmacy level while $5(45.5 \%)$ were from diluted pre-use or in-use samples in the pediatric/neonatal wards or the surgical wards. Chlorhexidine gluconate and cetrimonium bromide accounted for 9 of the 11 contaminated disinfectants/antiseptics $(81.8 \%)$, and chlorhexidine gluconate accounted for the remaining $2(18.2 \%)$. Only two of the four hospitals had contaminated disinfectant/antiseptic samples. All 24 isolates of Pseudomonas spp. tested were resistant to one or more of the 14 antimicrobial agents tested, with the prevalence of resistance to ciprofloxacin, norfloxacin, tobramycin, and gentamicin being $58.3 \%, 50.0 \%, 45.8 \%$, and $41.7 \%$, respectively.

Conclusions. Our results show that contaminated disinfectants/antiseptics pose a health risk to patients, particularly in the pediatric and surgical wards. The high prevalence of resistance to antimicrobial agents exhibited by the Pseudomonas spp. that were isolated is of special therapeutic concern.

Key words Disinfectants; anti-infective agents, local; hospitals, infection control; Pseudomonas; Trinidad and Tobago.

1 The University of the West Indies, Faculty of Medical Sciences, Pharmacy Programme, St. Augustine, Trinidad and Tobago.

2 The University of the West Indies, Faculty of Medical Sciences, School of Veterinary Medicine, St. Augustine, Trinidad and Tobago. Send correspondence to: Professor A. A. Adesiyun, School of Veterinary Medicine, Faculty of Medical Sciences, University of the West Indies, St. Augustine, Trinidad and Tobago; e-mail: abiodunadesiyun@ hotmail.com
Disinfectants and antiseptics of different preparations and concentrations have been used universally on animate and inanimate surfaces in hospitals (1-4). The observed increase in the resistance of a number of bacterial pathogens to some disinfectants and antiseptics has resulted in the develop- ment of new preparations as well as the introduction of various strategies to achieve optimal efficacy and effectiveness of disinfectants and antiseptics $(5,6)$.

It has been documented that stock solutions of disinfectants/antiseptics sold commercially, diluted disinfec- 
tants/antiseptics prepared in hospital pharmacies for distribution to the various hospital departments, and disinfectants/antiseptics that are in use in hospital departments have been exposed to contamination $(7,8)$. The levels of contamination by some of these bacteria have ranged from $10^{2}$ to $10^{8}$ colony-forming units per $\mathrm{mL}$ of disinfectant/antiseptic, with the possibility of attaining an infective dose at the site of application $(8,9)$. The public health significance of the use of contaminated disinfectants/antiseptics in neonatal units, surgical wards, and intensive care units cannot be overemphasized.

Reports of epidemics of nosocomial bacterial infections have implicated contaminated disinfectants/antiseptics both applied directly to the skin of animals or humans and used to decontaminate instruments and appliances used for diagnosis and treatment (10, 11). It has also been reported that contaminated disinfectants exhibit decreased efficacy and effectiveness (12, 13). Also of therapeutic significance are reports that a number of bacterial contaminants isolated from disinfectants have exhibited resistance to commonly used antimicrobial agents (14).

In the country of Trinidad and Tobago there is a dearth of information on the microbial contamination of disinfectants/antiseptics used in health institutions. This study was therefore conducted to determine the prevalence of bacteria in disinfectants/antiseptics at three levels: (1) pharmacy departments (pharmacy stock and diluted samples before delivery to wards), (2) pediatric/neonatal wards (after delivery from the pharmacy department, diluted pre-use and in-use samples), and (3) surgical wards (after delivery from the pharmacy department, diluted pre-use and in-use samples). The investigation also determined the sensitivity of the bacteria to antimicrobial agents.

Trinidad and Tobago, a twin-island republic in the Caribbean, has a population of 1.3 million people. Its health care system, which is currently undergoing structural reform, consists of a combination of public establishments (government hospitals, health centers, and other health institutions) and private establishments (hospitals, clinics, and nursing homes). The reform is an attempt to improve the delivery of public health care to its citizens, including reducing or eliminating contamination of disinfectants/antiseptics as well as of surgical equipment in the local hospitals.

\section{MATERIALS AND METHODS}

This study consisted of two parts: (1) a questionnaire component, used with 11 hospitals, and (2) a laboratory study on samples of disinfectants/ antiseptics collected in 4 of those 11 hospitals.

\section{Identification of commonly used disinfectants and antiseptics in 11 hospitals}

Initially, 11 health institutions in Trinidad were surveyed using a pretested standardized questionnaire to elicit information on disinfectant/antiseptic use. The questionnaire, which was administered to the head nurse and pharmacist, asked about the following subjects: types of disinfectants/antiseptics used, methods of preparation of disinfectants/antiseptics, conditions under which disinfectants/antiseptics are prepared, identification of potential sources of contamination, staff responsible for preparation and dilution of disinfectants/antiseptics, and potential use of disinfectants/antiseptics in the hospitals. Due to constraints with time, logistics, and resources, the main hospital in Tobago, the sister island, was not included in this study.

After analyzing the data from the questionnaires, we selected four health institutions, as these four prepared and utilized the largest volumes of disinfectants and antiseptics purchased by the Government and distributed to the pharmacy departments of these public health care institutions. These four hospitals are the largest public health care institutions in Trinidad. Three of these hospitals are located in the northern region of Trinidad, and the fourth is in the southern part of the island.

\section{Laboratory study of samples of disinfectants collected in 4 hospitals}

This cross-sectional study was designed to determine the bacteriological quality of disinfectants/antiseptics used in the four hospitals that we had selected. Each of the four hospitals was visited a total of four times, usually a week apart. Samples were collected at the three levels mentioned earlier: pharmacy departments, pediatric/neonatal wards, and surgical wards. The samples from each of the three levels at the four hospitals were given code numbers in order to avoid any bias in their analysis.

The study period lasted from January 2002 to March 2002. During each visit to the four hospitals, in the pharmacy departments we collected and placed approximately $10 \mathrm{~mL}$ each of the pharmacy stock and of the diluted pre-pediatric/pre-neonatal and presurgery samples into sterile universal bottles for our analysis. The pediatric/neonatal wards and the surgical wards served as the sources of diluted pre-use and in-use samples. All the samples were transported ice-cooled to the Public Health Laboratory of the School of Veterinary Medicine of the University of the West Indies, which is located in Champ Fleurs, Trinidad. The samples arrived at the laboratory within $2 \mathrm{~h}$ of collection and were processed immediately upon arrival.

At the laboratory, $1 \mathrm{~mL}$ of each of the samples was added to $9 \mathrm{~mL}$ of nutrient broth in new sterile universal bottles. This 1:10 dilution of the sample was thoroughly mixed using a vortex mixer. To quantify the aerobic bacteria in the samples, we used the procedure described by Khor and Jegathesan (15). With a micropipette, the 1:10 dilution of sample in nutrient broth was inoculated onto a dry nutrient agar plate. For each nutrient agar plate a total of 10 equally spaced $20-\mu \mathrm{L}$ inocula were placed on the plate. Thus, a total of $200 \mu \mathrm{L}$ of the 1:10 diluted sample 
was added to each plate. For each sample, duplicate inoculated plates were prepared. The inoculated plates were allowed to dry at room temperature $\left(25^{\circ} \mathrm{C}\right)$. Subsequently, one inoculated plate was incubated at $25^{\circ} \mathrm{C}$ for $72 \mathrm{~h}$, and the other plate was incubated at $37^{\circ} \mathrm{C}$ for $24 \mathrm{~h}$, both under aerobic conditions. The nutrient agar plates were observed for bacterial growths. The total count of colonies in the 10 areas (i.e., $200 \mu \mathrm{L}$ ) was determined and multiplied by 5 to determine the number of colonies per mL (1 $000 \mu \mathrm{L})$ of sample. Since each sample was initially diluted 1:10 in nutrient broth prior to plating on the nutrient agar plates, the number of colony-forming units per $\mathrm{mL}$ of disinfectant/antiseptic was determined by a further multiplication of the count by 10 .

To qualitatively determine the presence of aerobic bacteria in the samples, new duplicate sterile universal bottles were used. One of the bottles containing inoculated nutrient broth (1:10) was incubated at $25{ }^{\circ} \mathrm{C}$ for $72 \mathrm{~h}$, and the other bottle was incubated at $37^{\circ} \mathrm{C}$ for $24 \mathrm{~h}$, both under aerobic conditions. Growth in each broth was inoculated, without dilution, onto nutrient agar plates and incubated under the conditions to which the broths were initially exposed, that is, at $25{ }^{\circ} \mathrm{C}$ for $72 \mathrm{~h}$ and at $37^{\circ} \mathrm{C}$ for $24 \mathrm{~h}$, respectively. The outcome was expressed as positive or negative for aerobic bacteria.

Colonies representative of the various growths detected on the nutrient agar plates that had been incubated at $25^{\circ} \mathrm{C}$ and at $37^{\circ} \mathrm{C}$ were picked and streaked for isolation on blood agar plates and incubated at $25{ }^{\circ} \mathrm{C}$ for $72 \mathrm{~h}$ and at $37^{\circ} \mathrm{C}$ for $24 \mathrm{~h}$, respectively. All bacterial isolates were identified using standard methods (16). Confirmation of the isolates was done at the Caribbean Epidemiology Centre, Port of Spain, Trinidad.

The disk diffusion method (17) was used to determine the antibiotic sensitivity of the isolates, on Mueller-Hinton agar. A total of 14 antimicrobial agents were used at the following concentration: ceftriaxone (30 mg), streptomycin $(10 \mathrm{mg})$, ampicillin (10 mg), cephalothin $(30 \mathrm{mg})$, sulfamethoxa- zole/trimethoprim (30 $\mathrm{mg})$, neomycin (10 mg), nalidixic acid (30 mg), chloramphenicol $(30 \mathrm{mg})$, ciprofloxacin (5 mg), norfloxacin (10 mg), tobramycin $(10 \mathrm{mg})$, gentamicin $(10 \mathrm{mg})$, kanamycin $(30 \mathrm{mg})$, and tetracycline $(30 \mathrm{mg})$. Each isolate was incubated at the temperature and for the duration used for primary isolation, i.e., $25{ }^{\circ} \mathrm{C}$ for $72 \mathrm{~h}$ or $37^{\circ} \mathrm{C}$ for $24 \mathrm{~h}$.

The prevalences of bacterial contamination and of antibiotic resistance of isolates were compared for all samples using the chi-square $\left(x^{2}\right)$ test with Epi Info version 6.02 computer software (Centers for Disease Control and Prevention, Atlanta, Georgia, United States of America).

\section{RESULTS}

\section{Questionnaire survey of 11 hospitals}

According to the surveys done with the 11 hospitals, some of them used more than one source of water for diluting different disinfectants/antiseptics and for washing containers. Three of the health facilities used distilled water as diluent for preparing diluted disinfectants/antiseptics, 1 used boiled water, and 9 used pipeborne water supplied by the Water and Sewerage Authority (WASA), which is the Government agency responsible for the treatment and distribution of potable pipeborne water throughout Trinidad and Tobago. WASA water was directly used at 7 of the hospitals, while the other 2 used WASA water that had been stored in large tanks within the hospital premises. None of the 11 institutions used sterilized utensils in preparing the disinfectants/antiseptics, but 2 of the 11 hospitals utilized some apparatus to sterilize either the disinfectants/antiseptics or their containers. These containers are used to prepare or dilute the disinfectants/antiseptics and are also used for distribution of disinfectants/antiseptics to the pediatric/neonatal wards and the surgical wards. Pharmacists were responsible for preparing the disinfectants in 7 of the 11 health institutions, and hospi- tal attendants attached to the pharmacy departments performed this role in the other 4 hospitals.

All the disinfectants/antiseptics were distributed from the pharmacy departments to the pediatric/neonatal wards and the surgical wards in recycled, nonsterile, multiuse containers provided by the pharmacy departments. In some cases the containers were recycled bottles that originally contained the concentrated disinfectants/antiseptics, and in other instances they were glass bottles bought for this purpose. Concerning the use of antiseptics to clean skin surfaces, chlorhexidine gluconate (Hibitane) and chlorhexidine gluconate and cetrimonium bromide (Savlon) were most frequently used, each reportedly used by 6 of the 11 health facilities (54.5\%). Prior to administering an injection, 2 of the 11 hospitals (18.2\%) used swabs containing methylated spirit and 70\% alcohol to clean the skin. To clean inanimate surfaces, chlorhexidine gluconate was the most frequently used substance, used by 5 of the 11 hospitals $(45.5 \%)$. Chlorhexidine gluconate plus cetrimonium bromide was used by 3 of the 11 hospitals $(27.3 \%)$ to clean wounds.

\section{Laboratory study of samples from 4 hospitals}

From the 11 health facilities that we surveyed, 4 of them were selected to carry out laboratory studies to determine the bacteriological quality of the disinfectants/antiseptics that they utilized. We chose the 4 hospitals because they used the greatest volumes of disinfectants/antiseptics (chlorhexidine gluconate, chlorhexidine and cetrimonium bromide, and methylated spirit) as compared to the other 7 institutions that were involved in the questionnaire component of the study. Of the 4 hospitals, 2 used pipeborne water as well as boiled water for some preparations while the other 2 used distilled water.

Of the total of 180 tested samples from the four hospitals, 11 samples $(6.1 \%)$ were contaminated by aerobic 
TABLE 1. Prevalence of aerobic bacteria in disinfectants/antiseptics by source in four hospitals in Trinidad, 2002

\begin{tabular}{|c|c|c|c|c|}
\hline \multirow[b]{2}{*}{ Level/Type of sample } & \multirow{2}{*}{$\begin{array}{l}\text { No. of samples } \\
\text { tested }\end{array}$} & \multicolumn{2}{|c|}{ Samples contaminated } & \multirow{2}{*}{$\begin{array}{l}\text { TAPC of contaminated samples } \\
\left((\mathrm{CFU} / \mathrm{mL})^{\mathrm{a}}\right.\end{array}$} \\
\hline & & No. & $\%$ & \\
\hline \multicolumn{5}{|l|}{ Pharmacy departments } \\
\hline Pharmacy stock & 36 & 0 & 0.0 & $N A^{b}$ \\
\hline Diluted $^{\mathrm{C}}$ sample pre-pediatric/neonatal wards ${ }^{d}$ & 36 & 3 & 8.3 & $3.4210^{3},<10,{ }^{e}<10^{e}$ \\
\hline Diluted sample pre-surgery wards ${ }^{\dagger}$ & 36 & 3 & 8.3 & $3.2210^{4},<10,{ }^{e}<10^{e}$ \\
\hline \multicolumn{5}{|l|}{ Pediatric/Neonatal wards } \\
\hline Pre-use and in-use & 36 & 3 & 8.3 & $2.95210^{3}, 2.15210^{3},<10^{e}$ \\
\hline \multicolumn{5}{|l|}{ Surgical wards } \\
\hline Pre-use and in-use & 36 & 2 & 5.5 & $3.6210^{4}, 1.7210^{4}$ \\
\hline Total/Overall & 180 & 11 & 6.1 & NA \\
\hline $\begin{array}{l}\text { a Total aerobic plate count (TAPC) in colony-forming units } \\
\text { b NA = not applicable. } \\
\text { c Diluted with distilled, pipeborne, or boiled water. } \\
\text { d Diluted disinfectant/antiseptic samples destined for pediat } \\
\text { e Samples were negative for aerobic bacteria with the surfa } \\
\text { f Diluted disinfectant samples destined for surgical wards. }\end{array}$ & $\begin{array}{l}(\mathrm{CFU} / \mathrm{mL}) \text {. } \\
\text { wards. } \\
\text { hethod but grew aerc }\end{array}$ & owin & ative & \\
\hline
\end{tabular}

bacteria (Table 1). Of the 11 contaminated samples, 6 of them $(54.5 \%)$ were obtained in the pharmacy departments, and the other $5(45.5 \%)$ were pre-use/in-use samples obtained from the pediatric/neonatal wards or surgical wards.

Of the four health institutions studied, two of them had contaminated disinfectants/antiseptics. Of the three disinfectants/antiseptics studied, aerobic bacteria contaminated two samples; only the methylated spirit samples were completely free of contamination. All the bacterial isolates found in the contaminated samples were identified as Pseudomonas spp. For the contaminated samples, the sample with the highest aerobic plate count, of $3.6210^{4}$ colony forming units per $\mathrm{mL}$ (CFU/ $\mathrm{mL})$, originated from a surgical ward.

Table 2 shows the prevalence of aerobic bacteria found, by type of disinfectant/antiseptic and by level. All 60 samples of methylated spirit studied were free of aerobic bacterial contaminants. However, 2 of the 60 samples of chlorhexidine gluconate $(3.3 \%)$ were positive for aerobic bacteria, and 9 of the 60 samples of chlorhexidine gluconate and cetrimonium bromide were positive. The contamination of the 2 chlorhexidine gluconate samples occurred in the pharmacy departments. Of the 9 contaminated chlorhexidine gluconate and cetrimonium bromide samples, 4 of them were from the pharmacy departments, 3 were pre-use or in-use samples from pediatric/neonatal wards, and 2 were pre-use or in-use samples from surgical wards.

As mentioned earlier, all the bacterial isolates found were identified as Pseudomonas spp. The prevalence of resistance of these 24 isolates to the 14 antimicrobial agents is shown in Table 3 . Of the 24 isolates, all of them were resistant to one or more antimicrobial agents. The prevalence of resistance ranged from $25.0 \%$ (tetracycline) to $100 \%$ (ceftriaxone and streptomycin). The differences in prevalence of resistance to antimicrobial agents were statistically significant $\left(\chi^{2}\right.$ test, $\left.P<0.05\right)$. The patterns of resistance among the Pseudomonas spp. isolates were not significantly different across the three levels (pharmacy departments, pediatric/neonatal wards, and surgical wards).

\section{DISCUSSION}

The $6.1 \%$ prevalence of contaminated disinfectant samples from the four hospitals in Trinidad compares favorably with the $3 \%$ prevalence found in 11 Danish hospitals (18) and the $7.9 \%$ reported for Malaysian hospi- tals (19). Considerably higher prevalence levels have been reported for other countries, including $34.4 \%$ in $\mathrm{Ni}$ geria (7) and $43 \%$ in Japan (8). However, when comparing the frequency of contamination, one should consider the types and concentrations of disinfectants since resistance varies among microorganisms $(2,4)$.

The total aerobic plate count that we found, which ranged from under $10 \mathrm{CFU} / \mathrm{mL}$ to $3.6210^{4} \mathrm{CFU} / \mathrm{mL}$, is similar to reports by others, where the counts ranged from $10^{2}$ to $10^{8} \mathrm{CFU} /$ $\mathrm{mL}(8,9)$. The relatively high count of aerobic bacteria in the samples is indicative of the probability of attaining an infective dose and of establishing an infection $(20,21)$. The risk is further magnified when contaminated disinfectants are used in sensitive areas of the health facilities such as surgical wards and pediatric/neonatal wards. Clearly, any resulting nosocomial infections could have grave consequences $(20,22,23)$.

Of the three disinfectants/antiseptics investigated, chlorhexidine gluconate and cetrimonium bromide (which was a $1 \%$ concentration) was the most contaminated, with $15 \%$ of the samples positive for aerobic bacteria. Since similar practices took place in the preparation of the three disinfectants/antiseptics studied, it was 

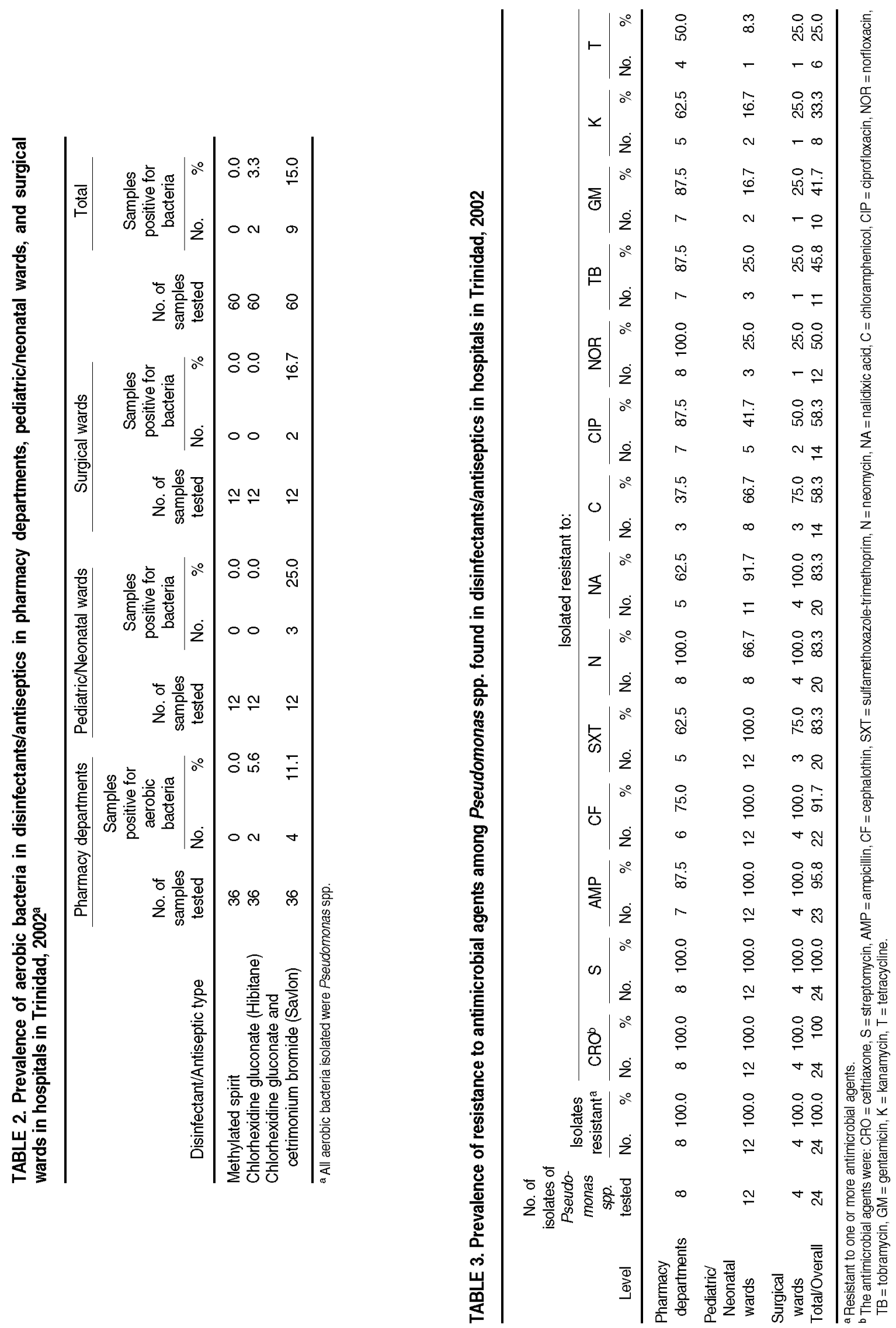
expected that they would all have been exposed to the same degree of contamination. However, the difference in the frequency of contamination may be explained in part by the low concentration $(1 \%)$ of chlorhexidine gluconate and cetrimonium bromide, which obviously was unable to inhibit or kill the contaminants. Given that this substance was the one that the 11 hospitals used most frequently to clean wounds, the health risks for patients in Trinidad are clear. Contaminated chlorhexidine gluconate and cetrimonium bromide was responsible for an outbreak of Pseudomonas maltophilia amongst Australian patients (20).

Of the 60 chlorhexidine gluconate samples in our study, only 2 of them $(3.3 \%)$ were contaminated by aerobic bacteria. Nevertheless, the fact this disinfectant was applied on skin surfaces did not entirely eliminate the risk that it poses to the patients in Trinidad. Other research (8) has reported a considerably higher prevalence, $60 \%$, for contaminated chlorhexidine gluconate samples.

All the samples of methylated spirit that we studied from all the sources were negative for aerobic bacteria. This suggests that the concentration of this antiseptic and its mode of activity completely eliminated all the contaminating aerobic bacteria that we found in the two other disinfectants that we studied. By its inherent nature, methylated spirit would not harbor microorganisms, and it is used in its original concentration from the supplier.

It was hardly a surprise that all stock solutions of the three disinfectants/antiseptics tested in all the pharmacies were free of aerobic bacteria. This could be explained in part by the high concentration of the active ingredient in the disinfectants/antiseptics prior to dilution, as well as the fact that they had not yet been exposed to potential environmental contamination.

It has been established that unsanitary practices during the preparation and distribution of disinfectants/antiseptics contribute significantly to their contamination in a hospital environment (10, 20, 22-24). For example, using inappropriate sources of water to dilute the disinfectants/antiseptics as well as failing to maintain adequate cleanliness of the disinfectant/antiseptic containers are important sources of bacteria. Deionized water used in diluting chlorhexidine gluconate and cetrimonium bromide was the source of $P$. maltophilia in a nosocomial epidemic in Australia (20). In Trinidad, pipeborne water has been reported to have a low residual chlorine level and high coliform counts $(25,26)$, contrary to the recommended zero tolerance for coliforms in potable water (27). Nevertheless, the pipeborne water at these four hospitals did not appear to be the main source of aerobic bacteria contamination. This is because aerobic bacteria were not detected in any of the disinfectant/antiseptic samples from the two of the four hospitals where disinfectant containers are subjected to a high temperature while undergoing two cycles each of wash and rinse, followed by autoclaving at $255^{\circ} \mathrm{F}$ at $15 \mathrm{lb}$ per square inch of pressure $\left(124^{\circ} \mathrm{C}\right.$ at $1.055 \mathrm{~kg} / \mathrm{cm}^{2}$ ) for 7 to $10 \mathrm{~min}$. Contaminated containers can contaminate disinfectants $(21,28)$.

Studies elsewhere have shown that in-use disinfectants are more heavily contaminated than diluted samples at the pharmacy level $(7,19,20)$. That is because the containers and the length of time that diluted samples are used in the wards affect contamination and the growth of bacteria. However, in our study, we did not individually trace the disinfectant/antiseptic samples in a longitudinal fashion from the pharmacy departments to the pediatric/neonatal wards or the surgical wards of the hospitals; we took samples at the hospitals only at weekly intervals. This limitation may partially explain our failure to detect a higher prevalence or counts of aerobic bacteria in the in-use disinfectant/antiseptics in the pediatric/neonatal wards and the surgical wards as compared with diluted disinfectant/antiseptic samples in the pharmacy departments awaiting distribution in the hospitals.

It was noteworthy that Pseudomonas spp. accounted for all the aerobic bacteria isolated from the disinfectant samples studied. Pseudomonas spp. have been reported to be the predominant aerobic bacteria recovered from contaminated disinfectants/antiseptics elsewhere $(8,19)$. It has also been reported that different Pseudomonas spp. vary in their resistance to disinfectants $(2,5)$. However, bacteria other than Pseudomonas have been isolated from contaminated disinfectants and have been implicated in nosocomial epidemics $(19,29)$.

Of therapeutic relevance is our finding that all 24 isolates of Pseudomonas spp. tested exhibited resistance to one or more of the 14 antimicrobial agents tested. In the health care delivery system in Trinidad and Tobago, in treating Pseudomonas spp. infections, gentamicin is the empirical choice for intravenous treatment of inpatients who have good renal functions, whereas ceftazidime is prescribed for patients with renal impairment (30). It is worrisome that $41.7 \%$ of the 24 isolates in our study were resistant to gentamicin and that $100 \%$ of them were resistant to ceftriaxone.

In Trinidad and Tobago one of the quinolones, ciprofloxacin, is the first line of oral therapy for Pseudomonas infections. Of the 24 isolates in our study, $58.3 \%$ of them were resistant to ciprofloxacin, again emphasizing the possible therapeutic consequences of infections that result from exposure to contaminated disinfectants/antiseptics.

In the high-risk areas of the hospitals (the pediatric/neonatal wards and the surgical wards) 5 out of the 72 samples of pre-use or in-use disinfectants/antiseptics were contaminated. This $6.9 \%$ prevalence is obviously unacceptable because of the health risk posed to patients in these sensitive areas. Combined with the relatively high counts of Pseudomonas spp. isolated, the high prevalence of resistance to antimicrobial agents commonly used in their control is definitely a source of concern. In order to minimize the risk posed to patients by contaminated disinfectants/antiseptics in health facilities in Trinidad and Tobago, we recommend that:

- Standardized guidelines for preventing microbial contamination of 
disinfectants/antiseptics be instituted and enforced in all hospital pharmacies.

- Functional autoclaves be provided by the Government to all public hospitals or health institutions that prepare solutions such as disinfectants/antiseptics for utilization in critical areas, e.g., pediatric/neonatal wards and surgical wards, in order to sterilize all disinfectant/antiseptic containers; in cases where the desired sterilization temperature is not achievable, all containers must be subjected to at least $100{ }^{\circ} \mathrm{C}$ prior to filling with disinfectants/antiseptics.
- Health facilities should be encouraged to use freshly prepared disinfectants/antiseptics and to institute measures to monitor (e.g., by expiry dating) diluted disinfectants/antiseptics to minimize prolonged use in the postdilution period; wherever possible, single-use containers, with a maximum volume of $500 \mathrm{~mL}$, should be introduced.

- Systems should be instituted to determine the microbial load of disinfectants/antiseptics, particularly of in-use preparations, in order to minimize the potential health risk that they pose. This can be done by rou- tine random microbiological sampling of disinfectant/antiseptic samples before leaving the pharmacy departments and while in use at their destinations in the hospitals.

Acknowledgements. We thank the Pharmacy Programme of the Faculty of Medical Sciences of the University of the West Indies for funding the project. We are grateful to Dr. I. Bekele and Ms. Nadira Seepersadsingh for their support. Ms. Jan Rodriguez is acknowledged for typing the manuscript.

\section{REFERENCES}

1. Newman KA, Tenney JH, Oken HA, Moody MR, Wharton R, Schimpff SC. Persistent isolation of an unusual Pseudomonas species from a phenolic disinfectant system. Infect Control 1984;5:219-222.

2. Whitmore E, McBee ML, Miner NA, Klasky S. Susceptibility of Pseudomonas to disinfectant. Respir Care 1975;20:745-749.

3. Winnefield M, Richard MA, Drancourt M, Grob JJ. Skin tolerance and effectiveness of two hand decontamination procedures in everyday hospital use. Br J Dermatol 2000; 143:546-550.

4. Bageant RA, Marsik FJ, Kellogg VA, Hyler DL, Gruschel DH. In-use testing of four glutaraldehyde disinfectants in the Cidematic washer. Respir Care 1981;26:1255-1261.

5. Russell AD. Bacterial resistance to disinfectants: present knowledge and future problems. J Hosp Infect 1999;43:S57-S68.

6. Rutala WA. APIC guidelines for selection and use of disinfectants. 1994, 1995 and 1996 APIC Guidelines Committee. Association for Professionals in Infection Control and Epidemiology, Inc. Am J Infect Control 1996;24:313-342.

7. Olayemi AB, Obayan Y. Contaminated disinfectants in health clinics in Ilorin, Nigeria. Infect Control Hosp Epidemiol 1994;15:581-582.

8. Oie S, Kamiya A. Microbial contamination of antiseptics and disinfectants. Am J Infect Control 1996;24:389-395.

9. Zembrzuska-Sadkowska E. Microbial contamination of pharmacies and hospital wards environment and its influence on the purity of prescription preparations during their production process as well as their application. Acta Pol Pharm 1995;52:67-75.

10. Keah KC, Jegathesan M, Tan SC, Chan SH, Chen OM, Cheong YM, et al. Disinfection: gaps between recommended and actual practice. Southeast Asian J Trop Med Public Health 1995;26:795-798.

11. Rutala WA, Weber DJ. Surface disinfection: should we do it? J Hosp Infect 2001;48: S64-S68.
12. Herruzo-Cabrera R, Uriarte MC, Rey-Calero J. Antimicrobial effectiveness of $2 \%$ glutaraldehyde versus other disinfectants for hospital equipment, in an in vitro test based on germcarriers with a high microbial contamination. Rev Stomatol Chir Maxillofac 1999;100:299305.

13. Kajanahareutai $S$, Rahule $S$, Sirikulsatein $P$, Sangkasuwan S, Yospol P. Efficacy and contamination of in-use disinfectants in Rajavithi General Hospital. J Med Assoc Thai 1995;78 Suppl 1:S36-S39.

14. Ayliffe GA. Hospital disinfection and antibiotic policies. Chemioterapia 1987;6:228-233.

15. Khor SY, Jegathesan M. In-use testing of disinfectants in Malaysian government hospitals. Med J Malaysia 1977;32:85-89.

16. Macfaddin JF. Biochemical tests for identification of bacteria. New York: Williams and Wilkins; 1980.

17. Baeur AW, Kirby WMM, Sherris JC, Turck M. Antibiotic susceptibility testing by a standardized single disk method. Am J Clin Pathol 1966;45:493-496.

18. Christensen EA, Jepsen OB, Kristensen $H$, Steen G. In-use tests of disinfectants. Acta Pathol Microbiol Immunol Scand [B] 1982;90: 95-100.

19. Keah KC, Jagathesan M, Tan SC, Chan SH, Chee OM, Cheong YM. Bacterial contamination of hospital disinfectants. Med J Malaysia 1995;50:289-290.

20. Wishart MM, Riley TV. Infection with Pseudomonas maltophilia hospital outbreak due to contaminated disinfectant. Med J Austr 1976;2:710-712.

21. Jones BL, Gorman LJ, Simpson J, Curran ET, McNamee S, Lucas C. An outbreak of Serratia marcescens in two neonatal intensive care units. J Hosp Infect 2000;46:314-319.

22. Zembrzuska-Sadkowska E. The danger of infections of the hospitalized patients with the microorganisms present in the preparations and in the hospital environment. Acta Pol Pharm 1995;52:173-178.
23. Fox JG, Beaucage CM, Folta CA, Thornton GW. Nosocomial transmission of Serratia marcescens in a veterinary hospital due to contamination by benzalkonium chloride. J Clin Microbiol 1981;14:157-160.

24. Ojajarvi J. Effectiveness of hand washing and disinfection methods in removing transient bacteria after patient nursing. J Hyg (Lond) 1980;85:193-203.

25. Welch P, David J, Clarke W, Trinidade A, Penner D, Bernstein S, et al. Microbial quality of water in rural communities of Trinidad. Rev Panam Salud Publica 2000;8(3):172-180.

26. Agard L, Alexander C, Green S, Jackson M, Patel S, Adesiyun AA. Microbial quality of water supply to an urban community in Trinidad. J Food Prot 2002;65:1297-1303.

27. World Health Organization. Guidelines for drinking-water quality. Health criteria and other supporting information. Geneva: WHO; 1993.

28. Anderson K, Keynes R. Infected corks closures and apparent survival of organisms in aseptic solutions. Br Med J 1958;2:27.

29. Hsueh PR, Teng LJ, Yang PC, Pan HL, Ho SW, Luh KT. Nosocomial pseudoepidemic caused by Bacillus cereus traced to contaminated ethyl alcohol from a liquor factory. J Clin Microbiol 1999;37(7):2280-2284.

30. Herfindal ET, Gourley DR, eds. Textbook of therapeutics: drug and disease management. Seventh ed. Philadelphia: Lippincott Williams and Wilkins; 2000.

Manuscript received 19 September 2002. Revised version accepted for publication on 3 March 2003. 
RESUMEN Objetivo. Evaluar la contaminación microbiana de los desinfectantes y antisépticos usados en cuatro grandes hospitales de la isla caribeña de Trinidad.

\section{La contaminación microbiana de desinfectantes y antisépticos en cuatro grandes hospitales de Trinidad}

Métodos. En este estudio de tipo transversal se tomaron muestras de desinfectantes y antisépticos obtenidos de los departamentos de farmacia, de las salas de pediatría y neonatología y de las salas de cirugía de cuatro hospitales. Las muestras fueron cultivadas en medio de agar nutritivo para bacterias aerobias mediante la técnica de siembra superficial. La sensibilidad de las bacterias aisladas a los antibióticos se determinó por el método de difusión en placa usando 14 antimicrobianos distintos. En total estudiamos 180 muestras de desinfectantes o antisépticos: 60 de gluconato de clorhexidina (Hibitane), 60 de gluconato de clorhexidina más bromuro de cetrimonio (Savlon) y 60 de alcohol metílico.

Resultados. De las 180 muestras estudiadas, 11 (6,1\%) estaban contaminadas con bacterias aerobias, invariablemente Pseudomonas spp. De las 11 muestras contaminadas, $6(54,5 \%)$ provenían de farmacias, mientras que $5(45,5 \%)$ correspondían a muestras de producto diluido obtenidas antes de usarse o mientras se usaba el producto en las salas pediátricas, neonatales y quirúrgicas del hospital. Nueve de los 11 $(81,8 \%)$ desinfectantes o antisépticos contaminados fueron una mezcla de gluconato de clorhexidina más bromuro de cetrimonio, y los 2 restantes $(18,2 \%)$ fueron solo gluconato de clorhexidina. Únicamente dos de los cuatro hospitales tuvieron muestras de desinfectantes o antisépticos contaminadas. Cada uno de los 24 aislamientos de Pseudomonas spp. mostró resistencia a uno o más de los 14 antimicrobianos de la prueba, y las prevalencias observadas de resistencia a ciprofloxacina, norfloxacina, tobramicina y gentamicina fueron de $58,3 \%, 50,0 \%, 45,8 \%$ y $41,7 \%$, respectivamente.

Conclusiones. Según estos resultados, la contaminación de desinfectantes o antisépticos constituye un peligro para la salud de los pacientes, sobre todo en las salas pediátricas y quirúrgicas. La alta prevalencia de resistencia a antimicrobianos que se observa en las Pseudomonas spp. aisladas en este estudio es especialmente alarmante. 